\title{
Violencia física y simbólica. Algunas reflexiones desde el audiovisual y sus discursos \\ Proyecto de Investigación 14.5
}

Equipo de Investigación

Zulema Marzorati y Mercedes Pombo por Facultad de Diseño y Comunicación, Universidad de Palermo (ARG) y Alejandra Rodriguez por Universidad Nacional de Quilmes (ARG)

Línea de Investigación 14. Cine y sociedad: Reflexiones sobre el cine contemporáneo

\section{Resultados publicados en el [Cuaderno 108] \\ Cuaderno del Centro de Estudios de Diseño y Comunicación No108. (2020/2021) \\ Violencia física y simbólica. Algunas reflexiones desde el audiovisual y sus discur- sos. Coordinación Zulema Marzorati, Mercedes Pombo y Alejandra Rodriguez. Programa de Investigación de la Facultad de Diseño y Comunicación. Centro de Estudios en Diseño y Comunicación. Facultad de Diseño y Comunicación. Uni- versidad de Palermo. Año XXIV. Buenos Aires, Argentina. ISSN: 1668-0227.}

Los resultados de este Proyecto de Investigación fueron evaluados por Patricia Galletti $y$ su Dictamen se transcribe a continuación:

\section{Síntesis de la Evaluación}

Actualidad de la temática (Vigencia, Aplicación) / Notable Nivel Alcanzado (Profundidad, Consistencia, Jerarquía) / Buena Diversidad del enfoques (Pluralidad, Participación) / Notable Calidad (Problemática, Análisis, Tratamiento) / Notable Contribución al avance del Diseño (Fortaleza) / Buena

\section{Fundamentos y Comentarios}

El resultado de las investigaciones integrantes del proyecto 14.5 "Violencia simbólica" publicado en el Cuaderno No 108 resulta de una gran pertinencia y actualidad, en tanto aborda dialógicamente las subjetividades implícitas (realizadores, espectadores, protagonistas) en el registro y proyección de material audiovisual relativo a las violencias históricas o presentes, reales o distópicas. Este libro expresa su fortaleza en el abordaje multidisciplinar a partir del estudio y análisis de registros documentales y ficcionales, que nos permiten 
pensar las violencias (físicas y simbólicas) desde estos espacios recreados para impulsar las prácticas de memoria, y para generar emociones a partir de su reflejo o resonancia en las imágenes audiovisuales proyectadas.

No encuentro tan clara la relación con su contribución al avance del diseño, esta intencionalidad no se encuentra explicitada en el cuaderno 108. No obstante, entiendo que representa un punto a favor la oportunidad de reflexionar sobre las violencias desde una óptica integral para emprender el diseño de cine y audiovisuales, conscientes de que su realización excede lo artístico, siendo su creación y presentación al público un hecho social, un fenómeno que abarca no solo a aquellos que forman parte de la industria del cine y los espectadores, sino también, en términos más amplios, a los efectos que la "vida" de este objeto desarrolla en la sociedad, como reflejo, como memoria, como recuerdo pasado o temor futuro del sufrimiento humano. 